\title{
The Impact of Managerial Compensation on Overconfidence: Based on Empirical Evidence of the Shenzhen A-share Listed Companies
}

\author{
Shengqiang LIU \\ Xiamen University, Xiamen, China 361005 \\ Chongqing Technology and Business University, Chongqing, China 400067
}

\begin{abstract}
Base on the sample of A-share listed companies of Shenzhen in China from 2007 to 2012, this article uses the random effect model to examine the impacts of managerial compensation on overconfidence and found that: managerial compensation has a positive effect on their overconfidence. Compared with nonstate-owned listed companies, enhancing management compensation of state-owned listed companies more easily lead to overconfidence.
\end{abstract}

KEYWORD: Management Compensation; Overconfidence; The Process of Marketization.

\section{INTRODUCTION}

With the eruption of a series of financial scandals such as Enron, WorldCom and so on, scholars are increasingly discovering that corporate governance mechanisms established in the traditional assumption of rationality did not play its due role. Some scholars think that the reason for the failure of corporate governance mechanisms is not the mechanism itself, but the mechanism of the person. Overconfidence refers to over-trust their own judgment, to overestimate their probability of success and accuracy of personal information. manager's overconfidence is one of the important reasons that lead to the alienation of the corporate decision-making behavior. This article takes A-share listed companies of Shenzhen in China from 2007 to 2012 as the sample, using the random effects model empirical to test manager compensation's influence on their overconfidence, looking forward to be able to provide some empirical evidence for optimizing manager compensation system and improving management decision-making behavior for listed companies.

\section{THEORETICAL ANALYSIS AND RESEARCH HYPOTHESES}

The traditional rational people assumption believes that people make decisions with consistent beliefs and preferences. When they receive new information, they will correctly adjust their beliefs according to Byes' rule, and then make decisions based on the standard of subjective expected utility maximization. However, psychological research has found that people are not entirely rational. Overconfidence refers to a psychological bias aroused from overestimating their own ability and knowledge in decision-making, which will lead to the resulting consequence that people overestimate the probability of success of their own decision-making and underestimate the risks associated with decision-making. It can be seen that managers pay is not a simple problem of redistribution of wealth, but the more important is that it gives managers psychological cognitive impact and the resulting distortions of the corporate decision-making behavior. Remuneratively behavioral concept more straightforwardly points out that manager salary is an important incentive for cognitive bias, and high pay not only gives managers the material compensation of hard work, but also gives the spirit compensation of recognition and success of individual abilities.

The relationship between manager pay and overconfidence not only lies in the absolute level of the remuneration, but also in the relative level, the gap of remuneration. The greater the relative gap of remuneration between CEOs and other executives, the more important they feel themselves, and the more arrogant they are.

Based on the above analysis, this article proposes the following hypothesis:

Assumption 1: Under the same other conditions, to improve the level of managerial compensation will lead to them overconfident.

In our country, the majority of listed companies are formed on the basis of restructuring the original state-owned enterprises. Due to the large and medium-sized state-owned enterprises are not only for the target to make profits, but also shoulder to fulfill the governmental many social responsibility to develop the local economy, promote employment and defend social stability and others. Therefore, the 
traditional profit index is not the best indicator to assess state-owned listed company. Compared with non-listed state-owned companies, managers' remuneration of state-owned listed companies more easily lead managers to be overconfident.

Based on the above analysis, this article proposes the following hypothesis:

Hypothesis 1.1: Under the same other conditions, compared to increasing managerial compensation of non-state-owned listed companies, improving the managerial compensation of state-owned listed companies will more easily lead to overconfidence.

China's market economy has been making great development since we implemented the policy of reform and opening up 30 years ago, but the degree of the process of marketization in China is very uneven across the country. Market economy has made a decisive development in eastern coastal areas, in which the degree of marketization is higher, and the relevant laws and regulations are more robust. However, the non-market factors still occupy a dominant position in the western inland regions. Under this institutional environment, the listed companies can better obtain the allocation of resources and advance the management of operation based on "hard" market-oriented principles. Manager salary contract system is easier to be well implemented, and is easier to lead managers to be overconfident.

Based on the above analysis, this article proposes the following hypothesis:

Hypothesis 1.2: Under the same other conditions, the higher degree of marketization of the local market of listed companies, and the higher level of managerial compensation, the easier to lead managers to be overconfident.

\section{RESEARCH DESIGN}

\subsection{Sample selection}

This article comply with the following principles to select samples: firstly, removes financial and ST listed companies; secondly, removes companies whose listed time is less than one year; thirdly, removes companies whose managers begin to serve this year; thirdly, removes companies whose managerial ownerships increase due to the reform of shareholder structure and equity incentive; lastly, removes companies whose data are not complete.

\subsection{Model design and variable selection}

This article constructs the following research model:

$$
\begin{aligned}
& \text { Confid }_{i, t}=\alpha+\beta_{1} \text { Sale }_{i, t-1}+\beta_{2} \text { Market }_{i, t-1}+\beta_{3} \text { Nature }_{i, t-1} \\
& +\beta_{4} \text { Dual }_{i, t-1}+\beta_{5} \ln \text { Size }_{i, t-1}+\beta_{6} \text { Roa }_{i, t-1}+\mu_{i, t}+\pi_{i, t}+\varepsilon_{i, t}
\end{aligned}
$$

In order to avoid endogen problems between explainable variables and explained variables, we will make explainable variable lag one period. In this model, $\mu_{i, t}$ is the company's individual effect, and $\pi_{i, t}$ is the annual macro environmental impact; $\varepsilon_{i, t}$ means the error term, and other variables' specific description as follows:

\subsubsection{Explained variables: managers' overconfidence (Confid)}

This article follows train of thought of Malmendier and Tate (2005), Ye Bei and Yuan Jianguo (2008) to choose the continuous variables of managerial ownership changes as measure index of managerial overconfidence. Specifically, it is to see whether managers increase holdings of shares in the company in the accounting year, the reason for which is executives themselves purchasing shares from two grade of market, subscripting shares, using the fund to buy shares, rather than the executives receiving bonus, bonus, equity division reform caused by the increase of holdings. At the same time, in order to eliminate the influence of equity division reform on the results of this study, the final formula of the index is: one plus (the number of the stockholdings of managers in the end of the year subtract the number of the stockholdings of managers in the end of last year subtract the number of the stockholdings that the company draws bonus to deliver this year) divide the number of the stockholdings in the end of last year.

\subsubsection{Explanatory variables: managers' salary}

Managerial compensation includes the level of managerial compensation and the gap of managerial compensation. This article uses the natural logarithm of the managers' pay to measure the level of a managerial compensation, and uses the difference between senior managerial personnel's salary and the average remuneration of the other members of the executive team to measure the gap of managerial compensation. The computation is divided into two steps, first of all, to calculate the average salary of the executive team after excluding managers, and the formula is: (the total salary of the executive team the salary of the managers) divides (the number of senior managerial team subtracts 1); Second, to calculate the gap of managerial compensation, and the formula is: (the number of managers' salary subtracts the average salary of the executive team after excluding managers) divides 10000 .

\subsubsection{Controllable variables: other factors that may have an impact on managerial overconfidence.}

This article mainly selects the following variables including: first, the enterprise's performance (Roa), and the value is the company's net profits divide average total assets; second, the company's scale (Size), and the value is the natural logarithmic of the company's total assets; third, the right nature of properties, and the value is one in state-owned listed companies, otherwise the 
value is zero; forth, the condition of the establishment of two powers (Dual), and the value is one if the chairman and general manager are served by one person, otherwise the value is zero; fifth, the degree of marketization of the local market of companies, the value is based on a commercialize report of Chinese various places, which Fang Gang and Wang xiaolu compiled in 2011.

\section{THE EMPIRICAL RESULTS AND ANALYSIS}

When using panel data, first of all, we need to judge the setting form of this model, as shown in table 1 , in the mode of the lever of managerial compensation, that the corresponding $F$ test value is 5.237, furthermore, it is significant in the lever of $1 \%$, which shows that fixed effects model (FE) is better than the model of mixture OLS model. From the same principle, it can be seen that random effects model (RE) is better than the mixed OLS mode and the Hausman chi-square test value show that random effects model (RE) is better than fixed effects model (FE). So this following article will only give the model of random effects in the grouping examination.

It can be seen from the table 1, in the case of controlling variables such as the year, whether we use mixed annual section data for regression or use the model of fixed effects or the model of random effects for estimation, the estimated coefficient values of the lever of managerial compensation are respectively $0.113,0.131$ and 0.167 , furthermore, they are all significant in the lever of $1 \%$, and the estimated coefficient values of the gap of the managerial compensation are respectively $0.049,0.046$ and 0.032 , furthermore, they are all significant in the lever of $1 \%$. It can be concluded that, in general, whether we raise the level or the gap of managerial compensation, they both may lead to managerial overconfidence, and the effect of overconfidence of managerial compensation is obvious, which verifies the hypothesis 1 .

Table 1: the empirical results of the whole samples

\begin{tabular}{|c|c|c|c|c|c|c|}
\hline \multirow[b]{2}{*}{$\cdot$} & \multicolumn{3}{|c|}{ The lever of managerial compensation } & \multicolumn{3}{|c|}{ The gap of the managerial compensation } \\
\hline & OLS & $\mathrm{FE}$ & RE & OLS & FE & RE \\
\hline $\mathrm{C}$ & $0.115(0.13)$ & $0.121(0.13)$ & $0.131(0.22)$ & $1.364 * * *(3.39)$ & $1.371 * * *(3.55)$ & $1.386 * * *(3.66)$ \\
\hline Sala & $0.113 * * *(2.92)$ & $0.131 * * *(3.15)$ & $0.167 * * *(3.27)$ & $0.049 * * *(2.79)$ & $0.046 * * *(2.88)$ & $0.032 * * *(2.82)$ \\
\hline Market & $0.003(0.26)$ & $0.024(0.31)$ & $0.059(0.23)$ & $0.061(0.4) 6$ & $0.066(0.32)$ & $0.068(0.25)$ \\
\hline Nature & $0.051(0.62)$ & $0.037(0.64)$ & $0.048(0.73)$ & $0.051(0.82)$ & $0.051(0.76)$ & $0.049(0.73)$ \\
\hline Dual & $-0.134 * *(-2.01)$ & $-0.143 * *(-2.13)$ & $-0.147 * *(-1.97)$ & $-0.151 * *(-2.12)$ & $-0.151 * *(-2.06)$ & $-0.155 * * *(-2.89)$ \\
\hline Size & $-0.037(-1.22)$ & $-0.032(-1.17)$ & $-0.037(-1.17)$ & $-0.041(-1.17)$ & $-0.037(-0.92)$ & $-0.032(-1.18)$ \\
\hline Roa & $-0.198(-0.42)$ & $-0.181(-0.31)$ & $-0.064(-0.22)$ & $-0.113(-0.33)$ & $-0.083(-0.26)$ & $-0.042(-0.25)$ \\
\hline Year & Control & Control & Control & Control & Control & Control \\
\hline $\mathrm{R} 2$ & 0.102 & 0.101 & 0.132 & 0.101 & 0.122 & 0.157 \\
\hline F value & $3.063 * *$ & 12.112 & 17.965 & 3.452 & 6.661 & 17.813 \\
\hline $\mathrm{F}$ test & \multicolumn{3}{|l|}{$5.237 * * *$} & \multicolumn{3}{|l|}{$7.852 * * *$} \\
\hline LM test & \multicolumn{3}{|l|}{$87.151 * * *$} & \multicolumn{3}{|l|}{$163.143 * * *$} \\
\hline Hausman test & \multicolumn{3}{|l|}{9.127} & \multicolumn{3}{|l|}{7.231} \\
\hline
\end{tabular}

Note: $* * *$ indicates in the significant level of $1 \%$, ** indicates in the significant level of 5\%, * indicates in the significant level of $10 \%, \mathrm{t}$ value in parentheses in Table 1 and 2.

Table 2: Empirical results of the random effects from grouping samples

\begin{tabular}{|c|c|c|c|c|c|c|c|c|}
\hline & \multicolumn{4}{|c|}{ The lever of managerial compensation } & \multicolumn{4}{|c|}{ The gap of managerial compensation } \\
\hline & Stateo-wned & $\begin{array}{l}\text { Non-state- } \\
\text { owned }\end{array}$ & $\begin{array}{l}\text { High } \\
\text { marketization }\end{array}$ & $\begin{array}{l}\text { Low } \\
\text { marketization }\end{array}$ & State-owned & $\begin{array}{l}\text { Non-State- } \\
\text { owned }\end{array}$ & $\begin{array}{l}\text { High } \\
\text { marketization }\end{array}$ & $\begin{array}{l}\text { Low } \\
\text { marketization }\end{array}$ \\
\hline $\mathrm{C}$ & $0.115(0.23)$ & $0.843(0.78)$ & $0.527(0.64)$ & $0.037(0.12)$ & $1.362 * * *(2.92)$ & $1.771 * *(2.51)$ & $2.071 * *(3.55)$ & $0.812 *(1.98)$ \\
\hline Sala & $0.127 * *(2.11)$ & $0.075(1.06)$ & $0.193 * *(2.03)$ & $0.093(1.22)$ & $0.051 * * *(2.91)$ & $0.007(0.41)$ & $0.037 * * *(3.25)$ & $0.003(1.17)$ \\
\hline Market & $0.055(1.15)$ & $-0.031(-1.03)$ & & & $0.020(0.62)$ & $-0.022(-0.92)$ & & \\
\hline Nature & & & $0.245 * *(2.13)$ & $-0.087(-1.16)$ & & & $0.161 *(1.87)$ & $-0.105(-1.23)$ \\
\hline Dual & $-0.179 * *(-1.79)$ & $-0.095(-1.04)$ & $-0.157 *(-1.62)$ & $-0.093(-0.43)$ & $-0.186 *(-1.98)$ & $-0.107(-1.02)$ & $-0.194 *(-1.91)$ & $-0.091(-0.98)$ \\
\hline Size & $-0.034(-0.87)$ & $-0.041(-0.56)$ & $-0.015(-1.65)$ & $-0.012(-0.54)$ & $-0.039(-1.21)$ & $-0.032(-0.65)$ & $-0.092(-1.61)$ & $-0.014(-0.52)$ \\
\hline Roa & $-0.581(-0.84)$ & $-0.272(-0.37)$ & $-0.411(-0.63)$ & $0.511(0.78)$ & $-0.542(-0.83)$ & $-0.191(-0.55)$ & $-0.215(-0.55)$ & $-0.533(-0.82)$ \\
\hline Year & Control & Control & Control & Control & Control & Control & Control & Control \\
\hline $\mathrm{R} 2$ & 0.122 & 0.115 & 0.116 & 0.112 & 0.123 & 0.113 & 0.107 & 0.122 \\
\hline Wald chi 2 & 12.76 & 4.123 & 12.93 & 5.22 & 17.72 & 2.92 & 13.42 & 5.17 \\
\hline Prob>chi2 & 0.0357 & 0.4316 & 0.0241 & 0.3854 & 0.0034 & 0.7083 & 0.0193 & 0.3983 \\
\hline
\end{tabular}

Taking the special type of property right of the listed companies in our country into consideration, this article is based on the actual controller, dividing samples into state-owned listed companies swatch group (referred to 
as state-owned groups) and non-state-owned listed companies swatch group (referred to as non-stateowned groups), respectively investigating the level and gap of managerial compensation how to affect overconfidence. Table 2 shows empirical results of the random effects of grouping samples, as is can be seen from the table that the effect which regardless of the level and gap of managerial compensation have on the managerial overconfidence both has a larger difference in the two samples: the estimated coefficient value of the lever of managerial compensation in the stateowned group is 0.127 , furthermore, it is significant in the lever of $5 \%$, however, the estimated coefficient value of the gap of managerial compensation is 0.051 , furthermore, it is significant in the lever of $1 \%$, and the level and gap of managerial compensation both don't pass the test of significance in the non-state-owned group. Hypothesis 1.1 has been verified.

In accordance with the process of marketization of the local market of listed companies is more than the median of the process of marketization index of our country or not, this article divides the sample into high market-oriented process group and the low marketoriented process group, respectively testing whether the links between managers and politics lead to overconfidence or not in the different institutional environment. As is shown in Table 2, the effect which regardless of the level and gap of managerial compensation have on the managerial overconfidence both has a larger difference in the two samples: the estimated coefficient value of the lever of managerial compensation in the high- market-oriented process group is 0.193 , furthermore, it is significant in the lever of $5 \%$, however, the estimated coefficient value of the gap of managerial compensation is 0.037 , furthermore, it is significant in the lever of $1 \%$, and the level of the level and gap of managerial compensation both don't pass the test of significance in the low market oriented process group. Hypothesis 1.2 has been verified. In the areas of the high- market-oriented process, listed companies can be more based on "hard" marketoriented principles for the allocation of resources and to manage the corporation's operation. The contract system of managerial compensation is easier to be implemented, but it is easier to lead managers to be overconfident.

It can be seen from the junction of tables 1 and 2, the combination of the two posts of chairman and general manager is less likely to lead to overconfidence, and this conclusion is habitually considered that the more combination of the two posts of chairman and general manager is, the more missing the monitoring mechanism is, the more easily lead to overconfidence with inconsistent views. This phenomenon may be the result that the internal corporate managerial system of our country is more complete in recent years, and the more combination of the two posts of chairman and general manager is, the more risk that managers take, and the more prudently when they make decisions, therefore, the lower the possibility of overconfidence is. Of course, the specific reasons still need the further inspection. The reason why the relationship between firm performance and overconfidence do not pass the significant test may be that the selected measure of overconfidence in this article excludes the factor of bonus. In the study we also find that overconfidence does not have the effect of scale.

\section{CONCLUSIONS}

This article found that, both of the level and gap of managerial compensation have a positive role in promoting managers' overconfidence. Compared with the non- listed state-owned, to improve the managerial compensation of state-owned listed companies is more easily lead to overconfidence. When the process of marketization of the local market of companies is not at the same level, under the higher marketization, the higher the managerial compensation is, the easier it is to lead to overconfidence. The possible reasons for this phenomenon is: managerial compensation give managers the recognition of individual capacity and success in the psychology which give managers a special kind of status and privilege in the real world, and this phenomenon in the state-owned company is more obvious compared to in non-listed state-owned companies, the reason for which is related to the longstanding phenomenon in state-owned listed company that property rights are not clear, and the ownership is absent, and internal control, and the operational aims are multiply. Managerial compensation is more easily lead to overconfidence under the higher marketization of the local market, which shows that we should pay more attention to the construction of the system itself in the progress of establishing the market economy.

\section{ACKNOWLEDGEMENT}

This paper is sponsored by the national social science funds (Grant NO: 14BJY083), the Humanities and Social Sciences Research Project from the Ministry of Education (Grant NO: 11YJC630139) and Postdoctoral Funds of China (Grant NO: 2013M530305).

\section{REFERENCES}

[1] Billett,M. Yiming, Qian. 2006. Are Overconfident Managers Born or Made? Evidence of Self-Attribution Bias from Frequent Acquirers, Working Paper, SSRN.

[2] Doukas J A. Petmezas D. 2007. Acquisitions, Overconfident Managers and Self-Attribution Bias. European Financial Management, (13): 531-577.

[3] Jensen, M., W. Meckling. 1976. Theory of the Firm: Managerial Behavior, Agency Costs, and Ownership Structure, Journal of Financial Economics, (3):305-360.

[4] Keiber K. 2002. Managerial Compensation Contracts and Overconfidence, Working paper, SSRN.

[5] Malmendier U. Tate G. 2005. CEO Overconfidence and Corporate Investment. The Journal of Finance, (6): 26612700.

[6] Malmendier U. Tate G. 2008. Who makes acquisitions? CEO Overconfidence and the Market s Reaction. Journal of Financial Economics, (89): 20-43. 